\title{
ERRATUM
}

\section{ATTRACTION OF BARK BEETLES (COLEOPTERA: SCOLYTIDAE) TO A PHEROMONE TRAP Experiment and Mathematical Models}

\author{
INGE S. HELLAND, ${ }^{1}$ JANN MORTEN HOFF, ${ }^{2}$ \\ and OLLE ANDERBRANT ${ }^{3}$ \\ ${ }^{1}$ Department of Mathematics and Statistics \\ Agricultural University of Norway \\ 1432 Aas-NLH, Norway \\ ${ }^{2}$ Zoological Institute, University of Oslo \\ P.O. Box 1050, Blindern, Oslo 3, Norway \\ Norwegian Forest Research Institute \\ P.O. Box 61, 1432 Aas-NLH, Norway \\ ${ }^{3}$ Department of Animal Ecology, Ecology Building \\ University of Lund, Helgonavägen 5, S-223 62 Lund, Sweden
}

Page 728, first paragraph under RESULTS, should read: ". . . and the origin (color) of all except one on the last day, could be determined."

\section{REFERENCE}

Helland, I.S., HoFf, J.M., and Anderbrant, O. 1984. J. Chem. Ecol. 10:723-752. 